\title{
Laboratory characterization and pilot site tests of residual sludge from dimension stones for civil and environmental applications
}

\author{
GIOVANNA ANTONELLA DINO*, MANUELA LASAGNA, \\ PAOLO CLEMENTE \& DOMENICO ANTONIO DE LUCA
}

\author{
Earth Sciences Department, University of Turin, Via Valperga Caluso, \\ 35 - 10125, Turin Italy \\ *Corresponding author (e-mail: giovanna.dino@unito.it)
}

\begin{abstract}
Residual sludge from dimension-stone working plants, both from gangue saws with abrasive shot and frame saws, is classified as waste and presents a number of problems for the stone industry. These problems include a fine size distribution, heavy metals and total petroleum hydrocarbon (TPH) content, all of which impede recovery and reuse. Residual sludge, management of which is administered in accordance with the Italian Legislative Decree 152/06, can be used in waste form for environmental restoration or for cement plants. However, it is also possible that sludge applications could go beyond these limited uses with incorporation of systematic treatment for the production of secondary raw materials (SRM), for example, filler, or for 'new products', for example, artificial loam. Such new products or SRM have to be certified not only on the basis of their technical and physical characteristics but also by means of appropriate chemical analyses to guarantee that the products are not contaminated.

This paper outlines the results from laboratory and in situ characterization of residual sludge. In particular, three potential applications of sludge either by itself or mixed with other materials were evaluated: landfill waterproofing material, filler material for civil works and artificial soil for land rehabilitation.
\end{abstract}

Residual sludge from dimension-stone working plants, represents a problem for the stone industry (Dino et al. 2003; Manning 2004; Sivrikaya et al. 2014). It is classified as waste (E. W. C. 010413) and is often disposed of in landfill sites, which conflicts with the European Union (EU) principles of 'resource preservation' and 'waste recovery'. The current cost associated with sludge landfilling can exceed $3 \%$ of operating costs for dimension-stone working plants, and its management is subject to periodic legislative regulation reform. In Italy, such waste materials are regulated by Legislative Decree (DLgs) 152/06, which permits sludge to be used as filler for land rehabilitation (in damaged or industrial areas) or as a feed material for different industrial uses (e.g. for a cement kiln). However, on the basis of two recent laws (L. 13/09 and DM. 61/ 12) residual sludge can be managed as 'soil and rock from excavation works' which will result in inevitable problems in legislative interpretation and administrative management.

The main problems related to sludge management are as follows (Dino et al. 2003):

(1) its size distribution (fine materials are potentially asphyxial for vegetation, see Burragato et al. 1999);

(2) the presence of Fe and heavy metals, primarily $\mathrm{Ni}$ and $\mathrm{Cr}$, present in the abrasive turbid and lime (used as an antioxidant) connected to the gangue saw with abrasive shot and $\mathrm{Cu}$ and Co from the diamond frame saw;

(3) the presence of total petroleum hydrocarbon (TPH), mainly due to oil machine losses.

If careful attention is paid to sludge management, treatment and characterization, economic and environmental benefits are possible. To achieve these benefits, it is necessary to consider systematic treatment of sludge to obtain secondary raw materials (SRM) or 'new products'. Such SRM or new products have to be certified not only on the basis of technical and physical characteristics but also by means of appropriate chemical analysis to guarantee that products are not contaminated. To boost their reusability they must be sent to a local treatment plant, which is often cheaper than disposing of them as waste. There are a number of factors that contribute to the viability of sludge treatment and reuse: the quantity of produced waste, which must be sufficiently large to justify the construction of a treatment plant; the quality of waste; the reliability of the waste source in terms of both consistent quantity and quality; transportation cost (ideally the source should be near the plant); and the market demand for products obtained from sludge treatment.

Waste on-site/off-site recovery and suitable reuse, although recommended by EU guidelines

From: Přırryl, R., TöröK, Á., Gomez-Heras, M., Miskovsky, K. \& Theodoridou, M. (eds) 2016. Sustainable Use of Traditional Geomaterials in Construction Practice. Geological Society, London, Special Publications, 416, 79-90. First published online March 16, 2015, http://doi.org/10.1144/SP416.9 (C) 2016 The Geological Society of London. For permissions: http://www.geolsoc.org.uk/permissions. Publishing disclaimer: www.geolsoc.org.uk/pub_ethics 
and Italian law, have encountered a number impediments, including the 'Nimby Syndrome', market suspicion towards recycled material regardless of qualification, and also controversial interpretation of existing waste legislation. In the Netherlands, the Flemish region of Belgium and, more generally, northern Europe, territorial environmental agencies recommend and promote the reuse of the treated matrix whenever possible instead of using natural materials considered as 'non-renewable resources'.

This study examines possible solutions related to sludge processing and application with the goal of making sludge reuse possible. The study begins with a brief description of what is considered the state of the art for sludge processing and application, and then presents results from this study which show the potential for residual sludges to be used as landfill waterproofing material, filler material for civil works and artificial soil for land rehabilitation.

The analysed sludge comes from dimensionstone working plants pertaining to the Verbano Cusio Ossola (VCO, NE Piedmont) quarry basin. This area is really important for the Italian dimension-stone economy: it is the foremost quarry basin of the Piedmont Region (NW Italy). The average annual production of residual sludge in this area is approximately 70000 tonnes; such a high sludge production causes huge costs for stone industries and environmental problems if not correctly managed. This residual sludge shows a siliceous matrix associated with granite and gneiss working activities.

\section{State of the art}

During the last 20 years, several studies have been conducted into the recovery of siliceous sludge for use as:

(1) waterproofing material for the bases and covering of urban landfills (Frisa Morandini \& Verga 1991; Dino et al. 2013);

(2) filler for civil works (Sassone \& Danasino 1995; DIADI 2000; Dino et al. 2013);

(3) artificial soil for land rehabilitation (Jim 2001; Carraro \& Castelli 2005; Dino et al. 2006, 2012; Molineux et al. 2009);

(4) stabilizers for clayey soil (Sivrikaya et al. 2014).

The first three of these reuse applications were considered as the basis for the present research on residual sludge from the VCO quarry basin.

\section{Most promising reuses of residual sludge}

Reuse as waterproofing for bases for urban waste disposal sites. Frisa Morandini \& Verga (1991) have highlighted that residual sludge, coming from siliceous dimension stone (in the Piedmont Region), shows a low hydraulic conductivity $(7 \times$ $10^{-7} \mathrm{~m} \mathrm{~s}^{-1}$ ). They added a small quantity of bentonite clay (3\%) to residual sludge (97\%), creating five $20 \mathrm{~cm}$ levels of residual sludge mixed with commercial bentonite clay. The results showed a hydraulic conductivity of approximately $9 \times 10^{-9}$ $\mathrm{m} \mathrm{s}^{-1}$ for the mix, guaranteeing that the material was impermeable and therefore could be used for landfill cover. An evaluation of sludge reuse for waterproofing purposes for urban waste disposal sites was also conducted in the Luserna stone quarry basin in 2004 (using untreated sludge, defined as sludge 'as such' (a.s.), for the covering of a local municipal landfill).

On the basis of this information, the research group involved in the present study decided to include reuse as an impermeable material in the experiments regarding residual sludge exploitation (Dino et al. 2015).

Reuse in the construction industry (civil and building industries). Different reuse applications for civil and building applications have been considered (Dino et al. 2003) as follows.

(1) Base material for decorative manufactured products: siliceous sludge a.s. could be used as an inert material in a cement mix to produce decorative objects (DIADI 2000). The results of the tests on different samples have shown that the obtained mix has suitable hydraulic properties and, furthermore, that the characteristics of the mix improve stress resistance during maturation in water. Sludge could be employed for construction of squared blocks for the building industry, kerbstones and urban decorative manufactured products, all of which would be characterized by a low price due to the incorporation of waste material (sludge).

(2) Base material for lightweight concrete production: lightweight concrete is characterized by a gradual addition of filler to improve the physical characteristics, by means of appropriate compactness, to obtain a superior stress path without sacrificing workability and durability of the concrete. It is necessary to increase the quantity of cement and to evaluate the appropriate size distribution to reduce the void ratio in the mixture. To obtain a suitable material (filler with a size dimension $<0.074 \mathrm{~mm}$ ) from the siliceous sludge, it is necessary to have an appropriate size distribution, a constant chemical composition, minimal water content and the separation of the abrasive metallic slurry component of the sludge from the gangue saw with abrasive shot. 
(3) Base for tile production: different tests have been carried out to evaluate the possible reuse of the sludge (from the gangue saw with abrasive shot and from the diamond frame saw) as clinker for tile production in substitution of the normally used colouring materials.

(4) Filler for bituminous conglomerates: for construction of pavements, a 5\% filler content is necessary in the ligament strata between the roadbed and the binder. A constant size distribution, reduction of water content and separation of the abrasive metallic slurry must be guaranteed to reuse sludge for this purpose.

(5) Filling materials for environmental rehabilitation, morphological remodelling, backfilling and engineering works: sludge a.s., certified to be absent of contaminated matter (potentially dangerous for the environment, see Italian law (DLgs 152/06), can be mixed with natural (or crushed) coarse materials and employed as filling materials for environmental rehabilitation, morphological remodelling, backfilling (Dlgs. 205/2010; L.116/2014) and engineering works (this is one of the possible reuse applications of sludge a.s. evaluated in the present research).

Land rehabilitation. Quarry rehabilitation is necessary to guarantee the environmental compatibility of quarry sites, both open and abandoned (Milgrom 2008). Such rehabilitation is mainly conducted employing materials that come from quarry and working-plant waste (not residual sludge because it can be employed only for damaged or industrial areas, and quarry areas are not deemed to have been 'damaged' by exploitation activities). Such materials show a lack of organic fraction so that farming applications of sludge a.s. are not feasible; the simple mixing with sand and the addition of NPK (nitrogen, phosphorus, potassium) elements do not alter the overall structure of the mixture or its contaminant content. The size of silt particles and minimal porosity mean that they are virtually impermeable, and furthermore, with progressive compaction and consequent potential asphyxia of vegetation (Burragato et al. 1999), these mixtures may represent a threat to soils in terms of surface erosion and permeability, and ultimately they increase the risk of landslides. The restoration of fertility is essential if we are to reuse these materials for environmental recovery; therefore, the physical and chemical structure of the sludge matrix should be properly characterized and declared appropriate for use.

A bioremediation treatment of the residual sludge is one way to qualify such waste, and although the approach is quite promising, it is still an experimental method not yet industrially applied.
Such treatment can improve soil characteristics (both physical and chemical) with a consequent improvement of the geotechnical features (Bending et al. 1999; Castillejo \& Castello 2010). Biological treatment is especially effective at removing pollution related to TPH/mineral oil contamination. A bioremediation process consists of composting a mixture of waste materials (mineral and organic) to which are added specific activators (Dino et al. 2006, 2012) to obtain artificial soil, which can be employed in the rehabilitation of quarries and civil works. Such a treatment guarantees a decrement in TPH content, improving the physical structure of the sludge a.s.

The products obtained at the end of bioremediation treatment are potentially useful for land rehabilitation, but current Italian legislation does not consider such materials as 'new/recycled products'; so, as of now, this treatment is only at the stage of experimental research. In the past we used products from bioremediation of sludge in an experimental quarry rehabilitation project (Cava del Tiglio, located in Pra del Torno, Rorà, NW Piedmont) with very positive results after 8 years (Dino et al. 2006, 2012); unfortunately such materials cannot be sold because they are not 'new products'. Instead, they are still considered 'waste' due to present national legislation.

In all the aforementioned potential applications, a sludge treatment process is needed to separate the metallic fraction (magnetic and hydrogravimetric separation, see Dino (2004)).

\section{Materials and methods}

Possible applications related to civil and environmental industries were considered for the present research. Residual sludge properties were first tested in a laboratory setting (Dino et al. 2013) and subsequently at pilot sites.

\section{Preliminary characterization in the laboratory}

The geotechnical characterization in the laboratory included grain size distribution analyses, Atterberg limits, falling-head permeability tests, direct shear tests and modified Proctor compaction tests.

The results obtained from the laboratory tests were fundamental for the evaluation of the characteristics of both the original materials and the new products obtained after the treatment. The potential uses of these new products were:

(1) landfill waterproofing or cover;

(2) filling materials for environmental rehabilitation, morphological remodelling, backfilling and engineering works (referred to as filler material);

(3) artificial soil for land rehabilitation. 
The grain size distributions were measured using sieve analysis according to the following ASTM standards: D421-85 (1998; 2007); D422-63 (1998; 2007); D1140-00 (2006); D2217-85 (1998). The results are reported as the mean soil fraction percentages, according to the AGI (Italian Geotechnical Association) classification (AGI 1994).

The Atterberg limits are a basic measure of the nature of a fine-grained soil. In this research, the plastic limit and liquid limit were assessed. The plastic limit was determined by rolling out a thread of the fine portion of a particular soil on a flat, nonporous surface. The procedure is defined in the ASTM standard D4318-10e1 (2010). For the liquid limit, the water content at which a soil changes from plastic to liquid behaviour was evaluated with a Casagrande standardized apparatus, according to the ASTM standard test method D4318-10e1 (2010).

The hydraulic conductivity was evaluated with falling-head permeability tests ASTM D5084-10 (2010) and ASTM D2434-68 (2006); in the fallinghead method, the soil sample is first saturated under a specific head condition, and then the water is allowed to flow through the soil without maintaining a constant pressure head. For two samples, the hydraulic conductivity was also measured with using a modified triaxial cell.

Direct shear tests were conducted to evaluate the stability of the material put on a slope. The tests were performed according the ASTM standard D3080M-11 (2011).

Finally, the modified Proctor compaction test is a laboratory method of experimentally determining the optimal moisture content at which the maximum dry unit weight is attained. The procedures used and equipment details for the modified Proctor compaction test are designated by the ASTM D1557-12 (2012).

The geotechnical tests were carried out on sludge a.s. combined with three different materials
(Table 1). The analysed sludge a.s. comes from different processes: residual sludge from the diamond-frame-saw process (referred to as ' $\mathrm{CG}$ '), the gangue-saw-with-abrasive-shot process (referred to as 'SR') or a mix of sludge from $\mathrm{CG}$ and $\mathrm{SR}$ (referred to as 'GG').

Depending on the hypothesized application, sludge a.s. was mixed with the following:

(1) bentonite clay for application in landfill waterproofing or cover;

(2) coarse materials (referred to as ' $\mathrm{COA}$ ') sourced from crushed dimension stones to serve as a filler material (for quarry or civil works pits);

(3) compost, sand and/or peat for artificial soil for land rehabilitation.

For the last mix, phytotoxicity tests were performed in cooperation with the Agricultural Department (DISAFA) of Turin University (UNITO).

The number of tests for each sample or mix is specified in Table 2.

\section{Pilot site tests}

Pilot sites were selected to reuse sludge a.s. mixed with coarse material (various mixture proportions were considered) as filling materials for civil works. The Pieve Vergonte area (VCO), NW Piedmont municipality, was selected for in situ experimentation, with tests being performed in an authorized landfill for inert waste (e.g. residual sludge, CER code 010413 ).

The three types of mix of sludge a.s. with local top soil (TS) used in the three pilot sites were as follows:

(1) Pilot site 1: MIX 1 (90\% sludge a.s. (GG) and $10 \%$ TS)

Table 1. Summary of analysed materials and their hypothesized applications

\begin{tabular}{|c|c|c|c|}
\hline $\begin{array}{l}\text { Analysed } \\
\text { material or mix }\end{array}$ & $\begin{array}{l}\text { Hypothesized } \\
\text { application }\end{array}$ & $\begin{array}{l}\text { Type of material } \\
\text { (mix) \% Dry Weight (D.W.) }\end{array}$ & $\begin{array}{l}\text { Sample } \\
\text { name }\end{array}$ \\
\hline $\begin{array}{l}\text { Sludge a.s. }+ \\
\text { bentonite clay }\end{array}$ & $\begin{array}{l}\text { (1) Landfill waterproofing } \\
\text { or cover }\end{array}$ & $\begin{array}{l}\text { CG + bentonite clay }(95: 5 \% \text { D.W. }) \\
\text { CG + bentonite clay }(90: 10 \% \text { D.W. }) \\
\text { SR + bentonite clay }(95: 5 \% \text { D.W. })\end{array}$ & $\begin{array}{l}\text { CG } 5 \% \\
\text { CG } 10 \% \\
\text { SR } 5 \%\end{array}$ \\
\hline $\begin{array}{l}\text { Sludge a.s. }+ \\
\text { coarse materials }\end{array}$ & (2) Filler material & $\begin{array}{l}\text { Coarse materials }(100 \%) \\
\text { GG + coarse materials }(90: 10 \% \text { D.W. }) \\
\text { GG + coarse materials }(80: 20 \% \text { D.W. }) \\
\text { GG + coarse materials }(70: 30 \% \text { D.W. })\end{array}$ & $\begin{array}{l}\text { COA } \\
\text { COA } 10 \% \\
\text { COA } 20 \% \\
\text { COA } 30 \%\end{array}$ \\
\hline $\begin{array}{l}\text { Sludge a.s. }+ \\
\text { sand, compost, } \\
\text { peat }\end{array}$ & $\begin{array}{l}\text { (3) Artificial soil for quarry } \\
\text { and civil works rehabilitation }\end{array}$ & $\begin{array}{l}\mathrm{GG}+\text { peat }(50: 50 \% \mathrm{vol}) \\
\mathrm{GG}+\text { compost }(50: 50 \% \mathrm{vol}) \\
\mathrm{GG}+\text { compost }+ \text { sand } / \\
\quad \text { peat }(50: 25: 25 \% \mathrm{vol})\end{array}$ & $\begin{array}{l}\text { I1 } \\
\text { I2 } \\
\text { I3 }\end{array}$ \\
\hline
\end{tabular}

Sludge a.s., sludge 'as such' (i.e. untreated sludge). 
Table 2. Summary of number of geotechnical tests performed on sludge a.s. and mixtures of sludge a.s. with other materials

\begin{tabular}{lccccc}
\hline $\begin{array}{l}\text { Sample } \\
\text { name }\end{array}$ & $\begin{array}{c}\text { Grain } \\
\text { size } \\
\text { analyses }\end{array}$ & $\begin{array}{c}\text { Atterberg } \\
\text { limits }\end{array}$ & $\begin{array}{c}\text { Falling-head } \\
\text { permeability } \\
\text { tests }\end{array}$ & $\begin{array}{c}\text { Modified } \\
\text { Proctor } \\
\text { compaction } \\
\text { tests }\end{array}$ & $\begin{array}{c}\text { Direct } \\
\text { shear } \\
\text { tests }\end{array}$ \\
\hline SR & 2 & 2 & 1 & 1 & 2 \\
CG & 2 & 2 & 1 & 1 & 2 \\
GG & 2 & 2 & 1 & 1 & 2 \\
COA & 2 & $/$ & $/$ & 1 & 2 \\
SR 5\% & 4 & 2 & 2 & 1 & 2 \\
CG 5\% & 2 & 2 & 1 & 1 & 2 \\
CG 10\% & 4 & 2 & 2 & 1 & 1 \\
COA 10\% & 1 & 2 & $/$ & 1 & 1 \\
COA 20\% & 1 & 2 & $/$ & $/$ & 1 \\
COA 30\% & 1 & 2 & 1 & 1 & 1 \\
I1 & 1 & 2 & 1 & 1 & 1 \\
I2 & 1 & 2 & 1 & 1 & 2 \\
I3 & 1 & 2 & & 1 & 1 \\
\hline
\end{tabular}

Sludge a.s., sludge 'as such' (i.e. untreated sludge); /, test not performed.

(2) Pilot site 2: MIX 2 (80\% sludge a.s. (GG) and $20 \%$ TS)

(3) Pilot site 3: MIX 3 (70\% sludge a.s. (GG) and $30 \%$ TS).

TS consisted of coarse and fine materials that were locally available. The pilot sites (Fig. 1) were set up on 23 July 2013. Each site had an average size of $3 \mathrm{~m} \times 3 \mathrm{~m} \times 0.4 \mathrm{~m}$ and all were characterized by a $30^{\circ}$ declivity; they were built on an artificial slope made of TS. After the mixing of the sludge a.s. with TS using a shovel excavator, the material was laid out on the slope in different layers and each layer was compacted.

Grain size analyses and direct shear tests were performed on the sludge a.s. (GG), TS and the three mixes used for the pilot sites (Table 3). As for the grain size analyses, the results are reported as the mean soil fraction percentages, according to the AGI classification (AGI 1994). Moreover, monitoring of the surface soil displacement with benchmarks was conducted at the three pilot sites. Specifically, four benchmarks were fixed on the surface of the sites; they were arranged as in Figure 1. The evaluation of the relative movements of the benchmarks (component parallel to the line of maximum slope) was performed by evaluating their displacement with respect to the reference benchmarks fixed outside the pilot site. The displacement measurements were made via tape with millimetre accuracy. The displacement measurements were performed during five different field surveys (31 July 2013, 7 August 2013, 13 September 2013, 21 October 2013 and 25 November 2013).

\section{Results}

Residual sludge from dimension-stone working plants of the VCO quarry basin, was analysed a.s. and also when mixed with other materials (bentonite clay, coarse crushed material and compost/sand/ peat) to evaluate its geotechnical parameters. The three potential applications of sludge a.s. or sludge mixtures were tested (i.e. as landfill waterproofing material, filler material and artificial soil for land rehabilitation).

During the research, laboratory and in situ characterization was undertaken in order to evaluate the effectiveness of the recovered sludge (sludge a.s or mixed) in the three above-mentioned applications. The laboratory phase was conducted in 2012, and the in situ phase lasted 12 months (from July 2013 to July 2014).

\section{Laboratory tests results}

The results of geotechnical tests on sludge a.s. and mixtures are summarized in Table 4. Sludge a.s. (SR, CG and GG), according to grain size distribution analyses, are clayey silt, weakly sandy; only one sample of the CG presented a size distribution as silt, weakly sandy and clayey. The results of the Atterberg limits indicate that the materials, characterized by sand fraction, are not plastic. The hydraulic conductivity $(\mathrm{k})$ is very low: fallinghead permeability tests yielded $\mathrm{k}$ equal to $2.3 \times$ $10^{-8} \mathrm{~m} \mathrm{~s}^{-1}$ for CG, $2.9 \times 10^{-8} \mathrm{~m} \mathrm{~s}^{-1}$ for SR and $9.2 \times 10^{-9} \mathrm{~m} \mathrm{~s}^{-1}$ for GG. The modified Proctor compaction tests indicate an optimal water content of $15 \%$ for CG and $14 \%$ for SR and GG. The peak 
(a)

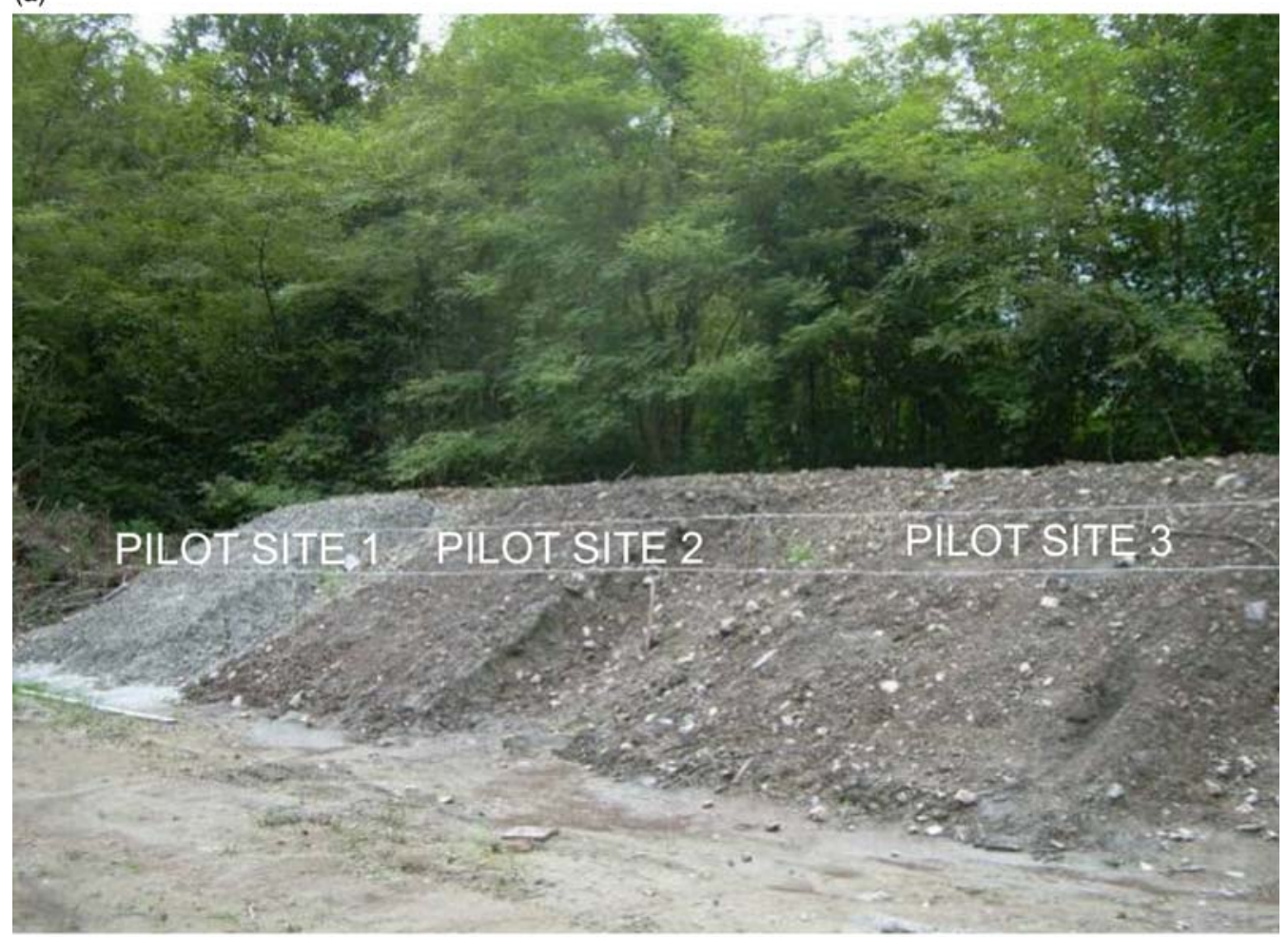

(b) Pilot site 1

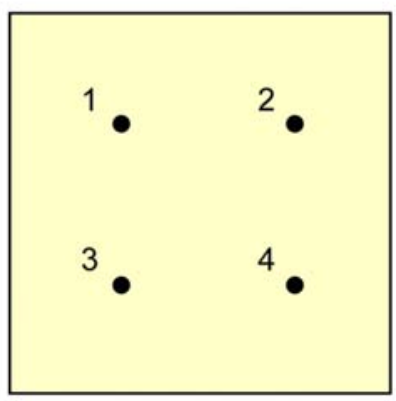

Pilot site 2

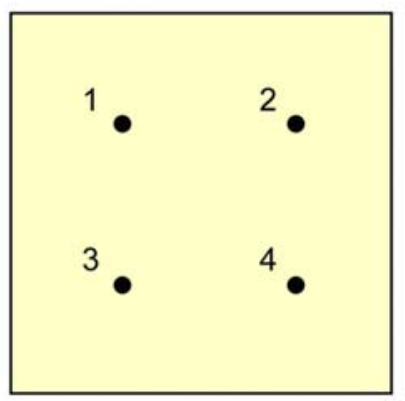

Pilot site 3

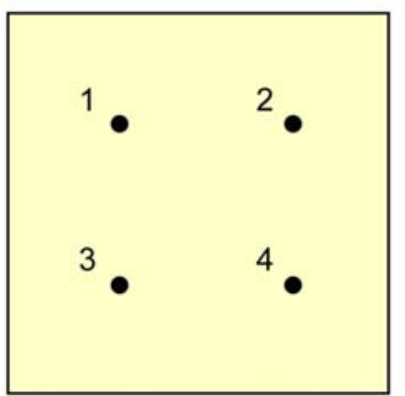

$1 \mathrm{~m}$

Fig. 1. (a) Pilot sites and (b) benchmark locations (black dot).

shear strength, according to the direct shear tests, ranged between: $34.2^{\circ}$ and $34.4^{\circ}$ for $\mathrm{CG} ; 36.7^{\circ}$ and $37.3^{\circ}$ for SR; $31.9^{\circ}$ and $33.0^{\circ}$ for GG. The results of geotechnical tests on mixes, realized for the three different potential applications, are described below (Dino et al. 2013).

Landfill waterproofing or cover. The mixtures of sludge a.s. and bentonite clay (SR 5\%, CG 5\% and
CG 10\%) present nearly the same size distribution of sludge a.s. (clayey silt, weakly sandy); only SR $5 \%$ presents size distributions in accordance with sandy, clayey silt. When a small percentage of bentonite clay is added to sludge a.s., the mixes show plastic behaviour. One of the most important parameters for evaluating landfill waterproofing or cover is the hydraulic conductivity, k. Indeed, according to Italian law (DLgs 36/2003), k has to 
Table 3. Summary of performed tests on sludge a.s.

\begin{tabular}{|c|c|c|c|c|}
\hline $\begin{array}{l}\text { Analysed material } \\
\text { or mix }\end{array}$ & $\begin{array}{l}\text { Sample } \\
\text { name }\end{array}$ & $\begin{array}{l}\text { In situ } \\
\text { application }\end{array}$ & $\begin{array}{l}\text { Grain size } \\
\text { analyses }\end{array}$ & $\begin{array}{l}\text { Direct } \\
\text { shear tests }\end{array}$ \\
\hline Mixed sludge & GG-PS1* & Pilot site $1^{\dagger}$ & 1 & / \\
\hline Mixed sludge & GG-PS2 & Pilot site 2 ; Pilot site 3 & 1 & 1 \\
\hline Local top soil & $\mathrm{TS}$ & Pilot site 1 ; Pilot site 2 ; Pilot site 3 & 1 & / \\
\hline sludge a.s $(90 \%) /$ local top soil $(10 \%)$ & MIX 1 & Pilot site 1 & 1 & 1 \\
\hline sludge a.s $(80 \%) /$ local top soil $(20 \%)$ & MIX 2 & Pilot site 2 & 1 & 1 \\
\hline sludge a.s $(70 \%) /$ local top soil $(30 \%)$ & MIX 3 & Pilot site 3 & 1 & 1 \\
\hline
\end{tabular}

Sludge a.s., sludge 'as such' (i.e. untreated sludge); /, test not performed.

* GG is a mix of sludge from diamond-frame-saw and gangue-saw-with-abrasive-shot processes.

${ }^{\dagger}$ Local top soil and the three mixes were employed for the pilot sites.

be $\leq 10^{-9} \mathrm{~m} \mathrm{~s}^{-1}$ for a landfill bed and $\leq 10^{-8} \mathrm{~m} \mathrm{~s}^{-1}$ for a landfill cover. Values of $k$ of analysed samples decreases when bentonite clay is mixed with sludge a.s. In particular, the addition of $10 \%$ bentonite clay greatly reduces $\mathrm{k}$ by two orders of magnitude, as measured with a triaxial cell.

The modified Proctor compaction tests indicate that adding bentonite clay $(5-10 \%)$ to sludge a.s. increases the optimal water content. The peak shear strength decreases slightly or remains constant with respect to sludge a.s.

Filler material. Sludge a.s. added to coarse materials (COA) could be used to fill quarry or civil works pits. Coarse materials, according to size distribution analyses, show a sandy gravel, weakly silty character. The mixes of sludge a.s. with coarse materials yield particle size distributions indicating sandy silt, weakly clayey and gravelly for COA $10 \%$, and silt, weakly gravely, clayey sandy for COA $20 \%$ and COA $30 \%$. Sludge mixed with coarse materials are characterized by having a sandy fraction and are not plastic. By adding coarse heterogeneous material (10-20\% coarse materials), both the optimal water content and the peak shear strength increase as compared to sludge a.s. (GG).

Artificial soil for quarry and civil works revegetation. The mixtures of sludge a.s. (GG) with sand, compost and peat that could be used for quarry and civil works rehabilitation, according to grain size distribution analyses, are silt, weakly clayey with sand (I1); silt, weakly gravely clayey with sand (I2); and sand with silt, weakly clayey (I3). Sludge mixed with other materials (sand, peat and compost) is characterized by a high sand fraction so that they are not plastic. The addition of sand, peat and compost to sludge a.s. (GG) increases the hydraulic conductivity and the peak shear strength relative to sludge a.s.

\section{Pilot site tests results}

The results of testing the use of sludge mixed with TS (coarse and fine materials) for quarry and civil works rehabilitation are reported below.

Size distribution analyses and direct shear tests on materials from the pilot sites. Grain size analyses and direct shear tests were performed on the materials used on the pilot sites, and the results are presented in Table 5. The peak shear strength for MIX 1, MIX 2 and MIX 3, according to direct shear tests, ranged between $31.8^{\circ}$ and $37.5^{\circ}$, which is somewhat lower than the values obtained during the laboratory phase (Table 4).

Monitoring of surface soil displacement with benchmarks. The relative movement of the benchmarks (i.e. the component parallel to the line of maximum slope), evaluated with respect to the reference benchmarks fixed outside of pilot site, are reported in Table 6 . Pilot site 1 showed good stability during the period of analysis (from July to December 2013), highlighting little or no movement of the benchmarks compared to the reference system. However, during the laying phase for pilot site 1, some movement of the surface soil was observed with the formation of trenches in the apex of the site and bulges in the downstream portions. One benchmark only showed displacements equal to $10 \mathrm{~mm}$ total compared to the reference system in the period of analysis. This dislocation was noted during the first field survey, just a week after the installation, and shortly thereafter, a layer of mud formed at the foot of the slope due to partial washout of the materials. Furthermore, the presence of incisions was observed along the main direction of the rainwater outflow, probably corresponding to the grooves left by the shovel which would have been made when the pilot set was marked out (Fig. 2). 
Table 4. Summary of the geotechnical test results for sludge a.s. and the mixtures

\begin{tabular}{|c|c|c|c|c|c|c|c|c|c|}
\hline \multirow[t]{2}{*}{$\begin{array}{l}\text { Sample } \\
\text { name }\end{array}$} & \multicolumn{4}{|c|}{$\begin{array}{c}\text { Mean soil fraction } \\
\text { percentage }(\%)\end{array}$} & \multicolumn{2}{|c|}{$\begin{array}{l}\text { Atterberg } \\
\text { limits }\end{array}$} & \multirow{2}{*}{$\begin{array}{c}\text { Hydraulic conductivity } \\
\mathrm{k}\left(\mathrm{m} \mathrm{s}^{-1}\right) \\
(\text { falling-head } \\
\text { permeability test })\end{array}$} & \multirow{2}{*}{$\begin{array}{c}\text { Optimal water } \\
\text { content }(\%) \\
\text { (modified } \\
\text { Proctor compaction } \\
\text { test) }\end{array}$} & \multirow{2}{*}{$\begin{array}{l}\text { Peak shear } \\
\text { strength } \\
\text { (direct shear } \\
\text { test) }\end{array}$} \\
\hline & $\begin{array}{c}\text { Gravel } \\
(2-60 \mathrm{~mm})\end{array}$ & $\begin{array}{c}\text { Sand } \\
(0.06-2 \mathrm{~mm})\end{array}$ & $\begin{array}{c}\text { silt } \\
(0.06-0.001 \mathrm{~mm})\end{array}$ & $\begin{array}{c}\text { clay } \\
(<0.001 \mathrm{~mm})\end{array}$ & $\begin{array}{l}\text { Liquid Limit } \\
\text { WL\% }\end{array}$ & $\begin{array}{c}\text { Plastic Limit } \\
\text { WP\% }\end{array}$ & & & \\
\hline SR & - & 8.9 & 72.2 & 18.9 & \multicolumn{2}{|c|}{ Not plastic } & $2.9 \times 10^{-8}$ & $14 \%$ & $36.7-37.3^{\circ}$ \\
\hline CG & - & 8.4 & 77.6 & 14.0 & \multicolumn{2}{|c|}{ Not plastic } & $2.3 \times 10^{-8}$ & $15 \%$ & $34.2-34.4^{\circ}$ \\
\hline GG & - & 6.5 & 75.3 & 18.2 & \multicolumn{2}{|c|}{ Not plastic } & $9.2 \times 10^{-9}$ & $14 \%$ & $31.9-33.0^{\circ}$ \\
\hline $\mathrm{COA}$ & 76.7 & 16.6 & 3.4 & 3.3 & \multicolumn{2}{|c|}{ / } & / & l & i \\
\hline SR 5\% & - & 14.9 & 69.3 & 15.8 & $39.7-40.5$ & 26.3 & $5.2 \times 10^{-9}-5.6 \times 10^{-9 *}$ & $18 \%$ & $36.8-36.8^{\circ}$ \\
\hline CG $5 \%$ & - & 10.3 & 71.3 & $\begin{array}{l}15.0 \\
18.4\end{array}$ & 39.7 & $29.2-31.0$ & $1.9 \times 10^{-9}$ & $17 \%$ & $28.9-29.3^{\circ}$ \\
\hline CG $10 \%$ & - & 6.0 & 77.0 & 17.0 & $36.3-37.2$ & $24.9-25.8$ & $2.3 \times 10^{-9}-4.2 \times 10^{-11} *$ & $16 \%$ & $33.7-35.2^{\circ}$ \\
\hline $\operatorname{COA} 10 \%$ & 8.5 & 12.4 & 66.2 & 12.9 & \multicolumn{3}{|c|}{ Not plastic } & $17 \%$ & $37.6^{\circ}$ \\
\hline COA $20 \%$ & 14.2 & 9.7 & 61.9 & 14.2 & \multicolumn{2}{|c|}{ Not plastic } & / & $18 \%$ & $38.1^{\circ}$ \\
\hline COA $30 \%$ & 15.7 & 9.0 & 61.3 & 14.0 & \multirow{2}{*}{\multicolumn{2}{|c|}{ Not plastic }} & 1 & $17 \%$ & $38.8^{\circ}$ \\
\hline I1 & - & 41.5 & 50.1 & 8.4 & \multirow{2}{*}{\multicolumn{2}{|c|}{ Not plastic }} & $6.8 \times 10^{-8}$ & / & $38.3^{\circ}$ \\
\hline $\mathrm{I} 2$ & - & 39.0 & 51.5 & 9.5 & & & $6.9 \times 10^{-8}$ & 1 & $36.1^{\circ}$ \\
\hline $\mathrm{I} 3$ & - & $\begin{array}{l}39.0 \\
49.3\end{array}$ & 42.8 & $\begin{array}{l}9.3 \\
7.9\end{array}$ & \multicolumn{2}{|c|}{$\begin{array}{l}\text { Not plastic } \\
\text { Not plastic }\end{array}$} & $5.2 \times 10^{-8}$ & t & $36.9^{\circ}$ \\
\hline
\end{tabular}

Sludge a.s., sludge 'as such' (i.e. untreated sludge); /, test not performed.

*Test performed with a constant flow in a modified triaxial cell (as comparison). 
Table 5. Summary of the size distribution analyses and direct shear test results performed on pilot site materials

\begin{tabular}{llccccc}
\hline & $\begin{array}{c}\text { Sample } \\
\text { name }\end{array}$ & \multicolumn{4}{c}{ Soil fraction percentage $(\%)$} & \begin{tabular}{c} 
Peak shear \\
strength \\
\cline { 3 - 6 }
\end{tabular} \\
\cline { 3 - 6 } & & $\begin{array}{c}\text { Gravel } \\
(2-60 \mathrm{~mm})\end{array}$ & $\begin{array}{c}\text { Sand } \\
(0.06-2 \mathrm{~mm})\end{array}$ & $\begin{array}{c}\text { Silt } \\
(0.06-0.001) \mathrm{mm})\end{array}$ & $\begin{array}{c}\text { Clay } \\
(<0.001 \mathrm{~mm})\end{array}$ & $\begin{array}{c}\text { (direct shear test) } \\
\text { Mixture }\end{array}$ \\
& MIX 1 & 21.6 & 6.9 & 60.8 & 10.7 & $31.8^{\circ}$ \\
& MIX 2 & 40.8 & 7.3 & 42.9 & 9.0 & $33.6^{\circ}$ \\
Sludge a.s. & MIX 3 & 32.8 & 17.2 & 44.4 & 5.6 & $37.5^{\circ}$ \\
& GG-PS1 & - & 7.8 & 79.6 & 12.6 & $/$ \\
& GG-PS2 & - & 8.0 & 81.7 & 8.0 & $/$ \\
\hline
\end{tabular}

Sludge a.s., sludge 'as such' (i.e. untreated sludge); /, test not performed.

Table 6. Total displacement of the benchmarks with respect to the benchmarks of reference fixed outside of pilot sites

\begin{tabular}{|c|c|c|c|c|c|c|c|}
\hline \multicolumn{2}{|c|}{ Benchmarks } & \multicolumn{5}{|c|}{ Displacement (mm) } & \multirow{2}{*}{$\begin{array}{c}\text { Total } \\
\text { displacement } \\
(\mathrm{mm})\end{array}$} \\
\hline & & $\begin{array}{c}23-31 \\
\text { July } 2013\end{array}$ & $\begin{array}{l}31 \text { July - } \\
7 \text { Aug } 2013\end{array}$ & $\begin{array}{c}7 \text { Aug - } \\
13 \text { Sept } 2013\end{array}$ & $\begin{array}{c}13 \text { Sept - } \\
21 \text { Oct } 2013\end{array}$ & $\begin{array}{c}21 \text { Oct }- \\
25 \text { Nov } 2013\end{array}$ & \\
\hline \multirow{4}{*}{$\begin{array}{l}\text { Pilot } \\
\text { site } 1\end{array}$} & Benchmark 1 & 10 & 0 & 0 & 0 & 0 & 10 \\
\hline & Benchmark 2 & 0 & 0 & 0 & 0 & 0 & 0 \\
\hline & Benchmark 3 & 0 & 0 & 0 & 0 & 0 & 0 \\
\hline & Benchmark 4 & 0 & 0 & 0 & 0 & 0 & 0 \\
\hline \multirow{4}{*}{$\begin{array}{l}\text { Pilot } \\
\quad \text { site } 2\end{array}$} & Benchmark 1 & 8 & 1 & 1 & 0 & 0 & 10 \\
\hline & Benchmark 2 & 0 & 0 & 0 & 0 & 0 & 0 \\
\hline & Benchmark 3 & 0 & 0 & 0 & 0 & 0 & 0 \\
\hline & Benchmark 4 & 0 & 0 & 0 & 0 & 0 & 0 \\
\hline \multirow{4}{*}{$\begin{array}{l}\text { Pilot } \\
\text { site } 3\end{array}$} & Benchmark 1 & 9 & 2 & 3 & 2 & 0 & 16 \\
\hline & Benchmark 2 & 3 & 1 & 1 & 6 & 0 & 11 \\
\hline & benchmark 3 & 0 & 0 & 0 & 0 & 0 & 0 \\
\hline & Benchmark 4 & 10 & 2 & 3 & 0 & 0 & 15 \\
\hline
\end{tabular}

(a)

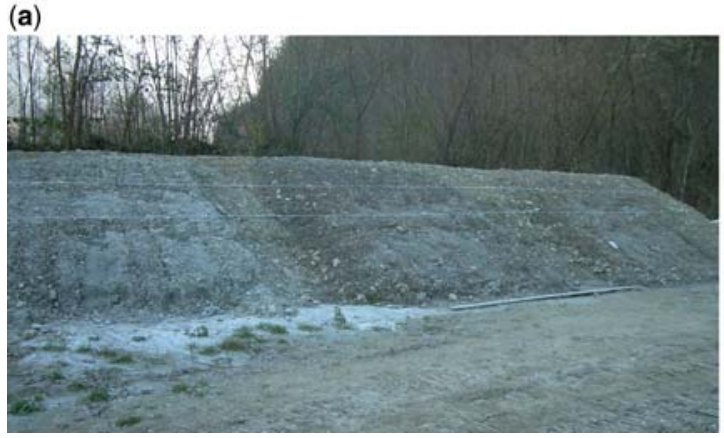

(b)

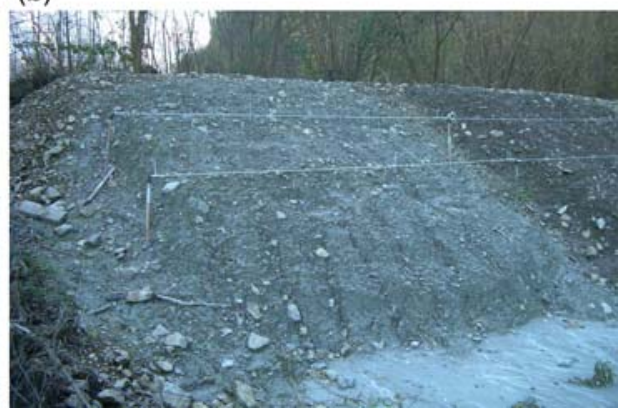

Fig. 2. (a) Morphological configuration of the pilot sites during the field survey of 25 November 2013; (b) details of pilot site 1 with a layer of mud at the foot of the slope and incisions. 
Pilot sites 2 and 3 showed a lower tendency for washout, and no trenches, bulges or incisions were observed at either site (Fig. 2). At pilot site 2, one benchmark showed a displacement of only $10 \mathrm{~mm}$ total compared to the reference system during the period of analysis. As for pilot site 3, benchmarks 1,2 and 4 present a total surface soil displacement equal to 16,11 and $15 \mathrm{~cm}$, respectively. Most of the benchmarks movement occurred in the first week after pilot site implementation.

\section{Discussion}

The focus of this study has been on the recovery of residual sludge from dimension-stone working activities. The tests were conducted on the three potential applications.

\section{Recovery as landfill waterproofing or cover}

Material for this purpose had been tested by Frisa Morandini \& Verga (1991) employing different materials and laboratory methods. For the 1991 study, the residual sludge came from the Luserna stone quarry basin, and showed physical and technical characteristics (e.g. grain size distribution, hydraulic conductivity) similar to sludge from the VCO quarry basin employed in the present research. Furthermore, there were differences between the present study and that in 1991, both the mixes in terms of percentages of raw materials used (the 1991 study used $97 \%$ residual sludge and $3 \%$ bentonite clay) and in actual procedures (the 1991 study used alternating layers of sludge and bentonite clay).

Although the previous research had showed promising results $\left(k=9 \times 10^{-9} \mathrm{~m} \mathrm{~s}^{-1}\right)$, the hydraulic conductivity obtained during the present research had lower values $\left(k=4.2 \times 10^{-11} \mathrm{~m} \mathrm{~s}^{-1}\right.$ : see Table 4). Such decrement is also due to a higher quantity $(10 \%)$ of bentonite clay in the mix. Furthermore, diamond-frame-saw sludge seems to guarantee better hydraulic conductivity.

\section{Recovery as filler material}

The results of laboratory and pilot site tests suggest that to obtain a product suitable for use as filler for civil works and quarry rehabilitation, it is sufficient to add $20-30 \%$ of coarse material to residual sludge. The pick shear test shows values always greater than $30^{\circ}$ (Tables $4 \& 5$ ). Sludge a.s. is not a natural material and it is characterized by angular grains. Consequently, the peak shear strength is higher than that of natural materials characterized by the same size distribution. Moreover, the presence of metallic elements (related to abrasive shot) also contributes to the same phenomenon.

\section{Recovery as artificial soil for rehabilitation}

Experiments to test the use of sludge for use as artificial soil for quarry and civil works rehabilitation were conducted with DISAFA (UNITO). The DST research group worked on the physico-mechanical characterization and the DISAFA research group worked on phytotoxity and agricultural characterization of the investigated products. The products show considerable promise for use in rehabilitation, both from a physical and agronomic point of view. If compared to results from previous research (Carraro \& Castelli 2005), which was conducted on sludge from the Canton Ticino $(\mathrm{CH})$ quarry basin, our mixes are characterized by a higher percentage of sludge (50\% compared to $30 \%)$; despite the higher percentage of sludge, the results obtained in the present study guarantee the right agronomic characteristics, and are comparable to those from the previous study.

\section{Conclusion}

The systematic recovery of residual sludge should be recognized by both private and public bodies as a means of promoting environmental and territorial protection and conservation of non-renewable resources. Sludge itself could represent an important alternative (integrating) source as a substitute to the exploitation of virgin materials (top soil, clay for waterproofing, etc.). Furthermore, its employment as waterproofing material, as filler and as artificial soil for rehabilitation can be a valid alternative to its disposal as waste.

The results obtained during the present research are promising. The employment of sludge as landfill waterproofing or cover material (sludge plus bentonite clay) seems to be guaranteed by low hydraulic conductivity (k) values of the mix. Indeed, according to Italian law (DLgs 36/2003), $\mathrm{k}$ has to be $\leq 10^{-9} \mathrm{~m} \mathrm{~s}^{-1}$ for a landfill base and $\leq 10^{-8} \mathrm{~m} \mathrm{~s}^{-1}$ for a landfill cover.

The physico-mechanical characteristics (evaluated during the laboratory and in situ phases) confirm that it should be possible to use the tested mixes as filler material and artificial soil for quarry and civil works rehabilitation. The next step should be the application of the products to specific quarries or civil yards, to evaluate if their application would guarantee the right physico-mechanical and agronomic characteristics, without causing air, soil and water pollution. If these studies were to be successfully carried out, then in terms of quarry 
rehabilitation, the 'cradle to cradle' principle would be totally applied: waste derived from quarry exploitation and working activities would be returned to the quarry. Such a sound procedure would guarantee both economic and environmental benefits:

(1) quarry enterprises would not have to buy the products useful for quarry rehabilitation, and moreover, they would not have to pay for sludge disposal, as sludge would be treated and partially or totally recovered (waste recovery principle);

(2) top soil would be preserved and employed for cultivation and not for the rehabilitation of damaged or industrial areas (resource preservation principle).

In general, to utilize sludge mixtures in civil and environmental applications, it will be necessary to guarantee, by means of appropriate chemical analysis, that there are no problems associated with soil, water and air pollution, which could potentially arise due to heavy metals and total petroleum hydrocarbon (TPH) content.

Furthermore, to produce a good-value product, it will be necessary to ensure the constancy of the "raw materials' and of the mixing procedures; these are fundamental to achieving the uniform distribution of all of the components required to obtain the desired products.

The authors would like to thank the Camera di Commercio di Verbania and the Centro Servizi Lapideo VCO for their support and cooperation during the work.

\section{References}

AGi (Italian Geotechnical Association) 1994. Raccomandazioni sulle prove geotecniche di laboratorio. Associazione Geotecnica Italiana, Roma.

ASTM D1140-00 2006. Standard Test Methods for Amount of Material in Soils Finer than No. 200 (75$\mu \mathrm{m})$ Sieve. ASTM International, West Conshohocken, PA. http://dx.doi.org/10.1520/D1140-00R06

ASTM D1557-12 2012. Standard Test Methods for Laboratory Compaction Characteristics of Soil Using Modified Effort (56,000 ft-lbf/ $/ \mathrm{ft}^{3}(2,700 \mathrm{kN}-\mathrm{m} /$ $\left.\mathrm{m}^{3}\right)$ ). ASTM International, West Conshohocken, PA.

ASTM D2217-85 1998. Standard Practice for Wet Preparation of Soil Samples for Particle-Size Analysis and Determination of Soil Constants (Withdrawn 2007). ASTM International, West Conshohocken, PA. http://dx.doi.org/10.1520/D2217-85R98

ASTM D2434-68 2006. Standard Test Method for Permeability of Granular Soils (Constant Head). ASTM International, West Conshohocken, PA. http://dx.doi.org/10.1520/D2434-68R06

ASTM D3080 - D3080M-11 2011. Standard Test Method for Direct Shear Test of Soils Under Consolidated Drained Conditions. ASTM International, West
Conshohocken, PA. http://dx.doi.org/10.1520/D3080_ D3080M-11

ASTM D4318 - 10e1 2010. Standard Test Methods for Liquid Limit, Plastic Limit, and Plasticity Index of Soils. ASTM International, West Conshohocken, PA. http://dx.doi.org/10.1520/D4318-10

ASTM D5084 - 10 2010. Standard Test Methods for Measurement of Hydraulic Conductivity of Saturated Porous Materials Using a Flexible Wall Permeameter. ASTM International, West Conshohocken, PA. http:// dx.doi.org/10.1520/10.1520/D5084-10

Bending, N. A. D., McRae, S. G. \& Moffat, A. J. 1999. Soil Forming Materials: Their Use in Land Reclamation. TSO, London.

Burragato, F., Mecella, G. \& Scandella, P. 1999. Waste muds from processing of the siliceous sands from Priverno: potential use for environmental rehabilitation. 2nd National Congress "Valorisation and recycling of industrial wastes". 5-8 July 1999, L’Aquila, Italy.

Carraro, G. \& Castelli, S. 2005. La valorizzazione dei fanghi di segagione: suoli artificiali ed impieghi di nicchia. In: Valorizzazione dei fanghi derivanti dalla lavorazione lapidea. Final report of Interreg IIIA project. Domodossola (VCO) - 15 December 2005, 10-11. Project coordinator: Provincia Verbano Cusio Ossola (IT) and A.I.G.T. (Associazione Industrie dei Graniti Marmi - $\mathrm{CH}$ ).

Castillejo, J. M. \& Castello, R. 2010. Influence of the application rate of an organic amendment (Municipal Solid Waste (MSW) Compost) on gypsum quarry rehabilitation in semiarid environments. Arid Land Research and Management, 24, 344-364. ISSN: 1532-4982 print 1532-4990, http://dx.doi.org/10. $1080 / 15324982.2010 .502920$

DIADI 2000. Recupero dei fanghi derivanti dalla lavorazione della pietra - Tecnoparco del Lago Maggiore unpublished report.

Dino, G. A. 2004. La gestione degli scarti dell'industria dei lapidei. PhD thesis. DIGET, Politecnico di, Torino.

Dino, G. A., Fiora, L., Fornaro, M., Gambelli, E. \& SANDRONE, R. 2003. Sludge production and management in the Italian Granite Stone industry: an example from two Granite Basins in the Alps. In: Erdogan, Y. (ed.) Proceeding of International Congress "Industrial Minerals and Building Stones". IMBS 2003 Istanbul - Turkey, 15-18 September 2003, 147-158.

Dino, G. A., Fornaro, M., Corio, E. \& Fornaro, E. 2006. Residual sludge management: a possible reuse as loam. The 10th IAEG Congress: Engineering Geology for Tomorrow's Cities, Nottingham, UK, 6-10 September 2006. Paper number 600.

Dino, G. A., Fornaro, M. \& Passarella, I. 2012. Innovative treatment and valorisation of waste coming from dimensional stones working plants: Piedmont samples. In: NziHOU, A. \& CASTRO, F. (eds) 4th International Conference on Engineering for Waste and Biomass Valorisation. 10-13 September, 2012 Porto, Portugal, 853-858. In Congess Procedia (CD ROM). ISBN: 979-10-91526-00-5, http://www.was teeng.org

Dino, G. A., Clemente, P., Lasagna, M. \& De Luca, D. A. 2013. Residual sludge from dimension 
stones: characterisation for their exploitation in civil and environmental application. Energy Procedia, 40, 507-514, http://dx.doi.org/10.1016/j.egypro.2013. 08.058

Dino, G. A., Clemente, P., Lasagna, M., Passarella, I., Ajmone Marsan, F. \& De Luca, D. A. 2015. Industrial chance to recover residual sludge from dimension stones in civil and environmental applications. In: Lollino, G., Manconi, A., Guzzetti, F., Culshaw, M., Bubrowsky, P. \& Luino, F. (eds) Engineering Geology for Society and Territory Volume 5, Urban Geology, Sustainable Planning and Landscape Exploitation. Springer International Publishing, Switzerland, 1309-1313. http://dx.doi.org/ 10.1007/978-3-319-09048-1_250

DLgS. 152/06: Decreto Legislativo 3 aprile 2006, n. 152 "Norme in materia ambientale". Published on G.U. n. 8814 April 2006 - Supplemento Ordinario n. 96.

Frisa Morandini, A. \& Verga, G. 1991. Problemi connessi con lo smaltimento dei residui di lavorazione delle pietre ornamentali. Marmomacchine, 102, $118-126$.
JIM, C. Y. 2001. Ecological and landscape rehabilitation of a quarry site in Hong Kong. Restoration Ecology, 9, $85-94$.

MANNING, D. 2004. Exploitation and Use of Quarry Fines. Miro Project Final Report. Mineral Solution LTD, Manchester (UK).

Milgrom, T. 2008. Environmental aspects of rehabilitating abandoned quarries: Israel as a case study. Landscape and Urban Planning, 87, 172-179.

Molineux, C. J., Fentiman, C. H. \& Gange, A. C. 2009. Characterising alternative recycled waste materials for use as green roof growing media in the UK. Ecological Engineering, 35, 1507-1513.

Sassone, P. \& Danasino, P. 1995. Caratterizzazione di fanghi di segagione di Pietra di Luserna per la valorizzazione come materie prime secondarie. 2nd International Meeting of Young Researchers in Applied Geology (IMYRAG), Peveragno, Italy, 11-13 October 1995, 510-515.

Sivrikaya, O., KiYIldi, K. R. \& Karaca, Z. 2014. Recycling waste from natural stone processing plants to stabilise clayey soil. Environmental Earth Sciences, 71, 4397-4407. 